\title{
Literary Representations of Capitalist Dictatorship in Transcultural Adaptations of Brecht's The Resistible Rise of Arturo Ui by Ajoka Theatre in Pakistan
}

\author{
Taimur Kayani \\ Faculty of Modern Languages and Communication, Universiti Putra Malaysia, Malaysia \\ Arbaayah Ali Termizi \\ Faculty of Modern Languages and Communication, Universiti Putra Malaysia, Malaysia
}

Received: 12-11-2016

doi:10.7575/aiac.ijclts.v.5n.1p.16
Accepted: 25-12-2016

Published: $31-01-2017$

\begin{abstract}
Brecht's 'canonical' literary work's indigenization in Pakistan can offer a valuable transcultural adaptation study because it was performed through a radical theatre with a distinct dramaturgy and political philosophy in two different cultural contexts and historical frame of references. As the foremost representative of Brecht's radical dramaturgy, philosophy and literary works in Pakistan since 1983, Ajoka theatre utilized these adaptations as socio-political spaces to challenge dominant discourses on the rise of dictatorship and capitalism in Pakistan. Prior studies explored the formal elements of these adaptations of The Resistible Rise of Arturo Ui(1942) : visual and aural and the intellectual content i.e. political dimension of this 'social action theatre' is still unexamined. This contextual reading attempts to fulfill this 'gap' by conducting a seminal contextual criticism on 'literary representations' of Pakistani pro-capitalist dictators in selected transcultural adaptations of Brecht's work in light of new historicism and Hutcheon's Theory of Adaptation. The article also explores how in the second phase Brecht's social and political philosophy is reflected in Ajoka's signature plays, Bala King (1997) and The Third Knock (1970).
\end{abstract}

Keywords: Transcultural Adaptation, Literary Representation of Dictators, Hutcheon's Theory of Adaptation, New Historicism, Foucault's Discursive Strategy

\section{Introduction}

Therefore learn how to see and not to gape.

To act instead of talking all day long.

\author{
The world was almost won by such an ape! \\ The nations put him where his kind belong \\ But don't rejoice too soon at your escape- \\ The womb he crawled from still is going strong \\ (Epilogue, The Resistible Rise of Arturo Ui)
}

Brecht acknowledges the repetition of 'history of tragedy' particularly the vicious cycle of re-birth of dictators in his satire on the passiveness of the society, The Resistible Rise of Artuo Ui(1942). According to him the only practical way out is to change the tragic and repetitive pattern of history by implementing the message of "social action theatre" which is to engage society for political resistance (Abdi 1987, Sporre 1993, Squiers 2012). Brecht as practical sociologist and as staunch social theatre advocate examines all kinds of variables in the re-birth of dictators and points out the significance of the 'missing intervention variable' in his selected literary work. That missing 'intervention' variable, according to him is the 'society response' to the first or initial action of dictator.The society can change the repetitive pattern by being vigilant and pro-active in response because "the womb he [dictator] crawled from still is going strong"(1).

Ajoka Theatre as an adaptor of Brecht's selected work in Pakistan has extended his philosophy and utilized this 'interventionist 'effect' of society in its first adaptation, The Third Knock (1970). It applied Brecht's political philosophy to exhibit the positive consequences of society's vigilance in order to resist dictatorship. In context of new historicism, specifically, Foucault and Greenblatt have examined these power relations. Greenblatt (1985) in Genre asserts that literature is but "another vision of history" (118) so we have a dominant discourse and a counter discourse in its resistance constantly in battle for the possession of 'discourse' of its time (Foucault 1995). 
1.1 Lack of Scholarly work on dictatorship in Pakistani context

Unfortunately, few studies have been carried out to evaluate the political effect of resistance discourse on society embedded in these three adaptations. It is pertinent to note that these plays were written against dictators with a capitalist mind set, performed publically at different historical framework. Specifically, in Pakistani context, three prominent dictators have been highlighted in the transcultural adaptations of The Resistible Rise of Arturo Ui , Nawaz Sharif in Bala King and General Ayub Khan and Zia-ul-Haq in The Third Knock.

Moreover, in Pakistan's context, Talbot (2012) points out the "lack of interest at the scholarly level" on General Ayub Khan (1958-69), Pakistan's first military dictator and whom capitalist legacy still casts its shadow over contemporary Pakistan. "There has been no major study since Lawrence Ziring's now classic text, The Ayub Khan Era: Politics in Pakistan, 1959-69" (75). Similarly, in case of Nawaz Sharif, who is among the few 'lucky' exiled civilian dictators regained power in 2013 and more importantly who "carried forward General Ayub's capitalist legacy to new heights" (Siddiqa 2008, Rehman 2012, Ayaz 2013), In addition, there are has been little critical discussion on their literary representation' as 'dictators' in general and in transcultural adaptations of Brecht's selected text, produced by Ajoka theatre in particular.

The article is important for at least three reasons. Firstly, it investigates the conflict between two economic systems i.e. capitalism and socialism which resulted in the emergence of dictatorship in Germany and Pakistan in two phases in light of new historicism to gain enhanced understanding and appreciation of The Resistible Rise of Arturo Ui (1942) and its transcultural adaptations in Pakistan. In first phase "historicizing literature" it analyzes the various events and movements in Nazi Germany (1933-45) and Zia's Pakistan(1977-88) to arrive at better understanding of Brecht's The Resistible Rise of Arturo Ui (1945) and Ajoka's adaptations, The Third Knock (1970) and Bala King (1997) Then in second equally important phase, which can be referred as "textualizing history" it examines the transcultural adaptions of Brecht's selected work to better comprehend the society and culture within which it was produced and received.

Secondly, in adaptation studies context, this research article also renders theoretical contribution to Hutcheon's theory of adaptation by engaging with the "historically conditioned reasons" that necessitated these adaptations. Hutcheon states:

Yet in literary studies, this dimension of response [Reasons behind adaptation] has been sidelined. However, adapters deeply personal as well as culturally and historically conditioned reasons should be considered seriously by adaptation theory, even if this means rethinking the role of intentionality in our critical thinking about art in general" (95)

Particularly in Pakistani context, the details discussion on emergence of martial law, rise of capitalism and dictatorship as the imperatives which played a pivotal role in producing these adaptations is also step towards enriching the political dimensions in theory of adaptation. At the article's center is the premise that due to the historic and geographical specifications related to the selected Brecht adaptation, the transcultural adaptation seems the appropriate literary vehicle to drive this Brecht's play into the next century, new geographical location and in different language.

\subsection{Reasons behind the emergence of dictatorship}

Ezrow and Frantz (2011) in their comprehensive work on dictators and dictatorship: Understanding Authoritarian regimes and their leaders enlist the reasons for its emergence:

Personalist dictatorship typically emerges following seizures of power in which the co-conspirator are not tightly organized enabling the leader to maximize power. Personalist dictatorship can also take shape in other scenarios, such as when democratically elected leaders implement constitutional changes enabling them to stay in power indefinitely. Such changes are possible primarily because the leader does not face a tightly organized group that is capable of resisting him (210).

This article is divided into three interrelated parts: the first part explores the relationship between concept of personalist dictatorship and Brecht's social and political philosophy in The Resistible Rise of Arturu Ui. The second section is dedicated to General Ayub Khan's personalist dictatorship and its literary representation in The Third Knock (1970), (2006) (1985).The third and final section explores the political commentary on civilian dictatorship in Bala King of Pakistan and examine how Ajoka 's Bala King plays out Brecht social and political philosophy in Pakistani context.

\section{Brecht's social and political philosophy against dictatorship in The Resistible Rise of Arturo Ui}

It has been argued that the striking difference between the Shakespeare's Richard III and its adaptation, The Resistible Rise of Arturo Ui by Brecht lies in their 'treatment' of history. Unlike Shakespeare's panoramic view of history, Brecht's 'glamour less world' (Fischlin \& Fortier, 2000) is a clear reflection of "consistent social and political point of view" (Willet 1959). Brecht describes his philosophy of history explicitly in the selected play as:

$\mathrm{Ui}$ is a parable play, written with the aim of destroying a dangerous respect commonly felt for great killers---- Plain every day logic must new let itself be overawed once it goes strolling among the centuries; whatever applies to small situations must be made to apply to big ones too. The petty rogue whom the rulers permit to become a rogue on the grand scale can occupy a special position in the roguery, but not in our attitude to history --- if the collapse of Hitler's enterprise is no evidence that he was a half-wit, neither is their scope any guarantee that he was a great man (3). 
It can be argued that emotional 'detachment' from its so-called great dictators gives his adaptation, The Resistible Rise of Arturo Ui, a new radical look even with the same thematic concern; vicious man rise to power. It also questions the society's submissive role in the rise of the dictators. He points his finger towards society and states, "the play is not so much an attack on Hitler, but rather upon the complacency of the people who were able to resist him, but didn't (15).

Ajoka theatre extends Brecht social and political philosophy in their two radically different representations of 'society response' to dictatorship. Firstly, in The Third Knock (1970) society responds with 'resilient' attitude while in Bala King with the 'submissive' attitude. Thus, sociologically, these selected literary works provide us valuable case studies to examine the effect of invention variable, which is the society attitude towards dictatorship.

In addition, , Fortier explores the relationship between the source text and its adaptation how they differentiate from each other and how they complement each other providing us the guideline which this study utilizes to analyze the two adaptations in light of Brecht's The Resistible Rise of Arturo Ui.

\subsection{Representation of Capitalist dictatorship in historical texts}

In light of new historicism, three other non-literary texts are selected to re-examine Brecht's Marxist discourse in The Resistible Rise of Arturo Ui on nexus between dictatorship and capitalism which according to him gave birth to Fascism. Firstly, Mein Kampf (My struggle) by Adolf Hitler (1925), The Collected Essays, Journalism and Letter of George Orwell, Volume 2 (1940), The Third Reich: Politics and Propaganda (1993) by David Welch and seminal and groundbreaking work on Nazi privatization in 1930s Germany by Germa Bel (2012) will be examined to unleash the representation of capitalist dictatorship during Brecht's time.

For contextual reading, it seems Hitler book, Mein Kampf, is a highly valuable philosophical document of Fascism , which as an ideology which advocates that "there is a hierarchy in society and the strongest profit and the weak fall away. Those that own land and have money deserve it and the working man is there to provide profits for rich" (OCR 2016). One can see the reflection of capitalism in this philosophy. Mien Kampf also endorses the value of propaganda to advance fascist ideology. It is pertinent to view Brecht's work as 'counter discourse' to this ideology promoted heavily by Hitler's Mein Kampf .

Hitler devotes two chapters to the study and practice of propaganda. He recollects the significance of it still his student days. He writes that "the correct use of propaganda is true art which has remained practically unknown to the bourgeoisie parties" (10). Unlike Brecht's Epic theatre, who engages the spectator's rational powers of observation rather that playing on the spectators feeling proceeding by argument rather suggestion, Hitler theatre of Power performance thrived on the opposite principles of Epic theatre. In Mein Kampf, Hitler lays down the broad lines along which Nazi propaganda was to operate, he assess his audience as follows:

The receptivity of the great masses is very limited, their intelligence is small, but their power of forgetting is enormous. In consequence, all effective propaganda must be limited to a very few points and must harp on these in slogans until the last member of the public understand what you want him to understand by your slogan (11).

Interestingly, Orwell (1940), in The Collected Essays, Journalism and Letters exhibited the same thematic concerns Brecht highlighted in The Resistible Rise of Arturo Ui. He understood the significance of Mein Kampf and like Brecht was wary and frustrated with the consequences unfolding due to his Fascist philosophy and propaganda abilities of Hitler team expressed implicitly in the selected playtext.

Orwell asserts in March, 1940 that the world should not underrate the emotional appeal of Hitler propaganda and criticized the counter discourse for its ineffective presence consequence would be devastating:

All three of these dictators have enhanced their power by imposing intolerable burdens on their peoples. Where Socialism and even capitalism in a more grudging way have said to people "I offer you good time," Hitler has said to them "I offer you struggle, danger and death" and as a result a whole nation flings itself on his feet. Perhaps later they will get sick of it and change their mind, as at the end of the last war. After a few years of slaughter and starvation "Greatest happiness of the greatest numbers" is a good slogan, but at this moment "Better an end with horror than a horror without end" is a winner. Now that we are fighting against the man who coined it, we ought not to underrate its emotional appeal (11).

This submissive attitude of the 'submissive German society' shown in The Resistible Rise of Arturo Ui which has surrendered its right to fight against the fascist dictator is also shown by Welch in The Third Reich: Politics and Propaganda (1993). Ui is about Hitler, how he rises in power and what he does to achieve it. It's about how he uses the society and manipulates people's unhappiness and despair to achieve his dark purposes. Let see the similarities in both texts:

In the final stages of Nazis 'rise to power, circumstances conspired to make the rise easier. Not only did Hugenberg's press and Film Empire help legitimize the party, but German industry was also providing valuable resources which allowed the Party to escalate its propaganda campaigns (14). 
Another significant document which investigates the nexus between the capitalist industrialist and Hitler's accession to power is Maxine Sweezy's seminal work (1941) on privatization in Nazi Germany. In Structure of the Nazi Economy, Sweezy endorses the idea that Nazi privatization policy was policy devised in return for business assistance (27).

According to Sweezy, Hitler 'paid back' the business sector that supported him wholeheartedly in his accession to power and his economic policies "by restoring to private capitalism a number of monopolies held or controlled by state (27). This policy actually was applied a large-scale program by the government transferred ownership to private hands" (28). It is pertinent to note the against the mainstream Germany was only country in 1930s who conducted privatization policy (Bel 2014) further establishes the key role of big business in bringing and sustaining Hitler regime.

\section{The Third Knock: Extension of Brecht's social and political Philosophy}

The Third Knock (1970) uses the 'advocacy function' of theatre which means “stirring the audience to strong social and political action outside theatre" (Sporre 1993). It prescriptive criticism on dictatorship asks the society to take action.

Like in Germany in 1930s, we see the same kind of 'contextual factors' and 'variables' brought the dominant discourse on dictatorship in Pakistan. The natural alliance between capitalism, bourgeoisie class and dictatorship paved the way for the dictatorship in Pakistan just like it did in Germany in 1930s.

It is an assumption of Greenblatt's approach to new historicism that similarities between such an array of texts form a discourse, which inevitably shapes and determine the views, values and actions of the society and culture in which it is fostered (Williams 2014).

Importantly, there seems no difference in the official statements after taking over the country by all the three dictators presented in The Third Knock, in adaptation of Arturo Ui . Let's examine their statements one by one, which builds 'episteme' for dictatorship necessity in Pakistan.

First, General Ayub Khan, the first military dictator of Pakistan, delivered a withering attack on the politicians "after taking the business elite in confidence" (Talbot 2012, Ziring 1990), claiming that they have waged:

“.... A ceaseless and bitter war against each other regardless of ill effects on the country just to whet their appetites and satisfy their base demands. There is no limit to the depth of their baseness, chicanery, deceit, and degradation (76)

History official books which are written exclusively for students in public schools and colleges seem subservient to this discourse against politics and politicians in general and replicate the ideology of dictatorship necessity in Pakistan. "It becomes a duty of the textbook writer to bring its need of tribute to the General in power" (Aziz 1993). Various examples can be cited to view the discourse develop to encourage dictatorship and to discourage democracy. For instance, Federal Government Bachelor of Art prescribed book proudly declares in respectful submission to the military dictatorship:

He took over power to save the administration form disorder because of the wrong policies and irresponsibility of selfstyled political leaders, the country stood at the brink of disaster, and the need of a strong government was greatly felt. In these circumstances, General Muhammad Ayub khan (Late) imposed Martial law (38).

Likewise, in History of Pakistan:1708-1977 by Malik concludes his discourse on Bhutto regime with the appeasement to military regime; "the present Army government, under the leadership of General Muhammad Zia-ul Haq, turned the national foreign policy in the right direction, exactly as required by the interest of the country and the nation"(440).

Similarly, Lawrence Ziring (1997) renowned historian who seems to be sided with the dictatorial regimes added to the discourse in the favor of dictatorship happily confirms the "Spontaneous celebrations spread throughout the country" among the common masses in greeted the Martial law on the roads. He even quotes Fatima Jinnah leading politician and sister of the founder of Pakistan who supposed to resist the Martial law actually supported it with blessings thus exhibited the 'submissiveness' of the leaders of the society to the resistible rise of Muhammad Ayub Khan . Miss Fatima Jinnah summed up the revailing sentiments according to Ziring in the following words:

A new era has begun under General Ayub Khan and the Armed forces have undertaken to root out the administrative malaise and the anti-social practices, to create a sense of confidence, security and stability and eventually to bring back to normalcy. I hope and pray that God may give them wisdom and strength $t$ achieve their objectives (225).

It is clear that Ziring narrative, like Malik's history replicates the ideology of dictatorship. In Malik's and Ziring texts dictatorship is also redeemed by an ideal of order, efficiency and civilization brought by the military dictatorship and stamped indelibly on the dictator thus we see a 'system of representation' or 'discursive formation' which is perfectly closed and circular. It can be observed in all of these texts the subversive potential of the societal view of dictator ship is never possible because every time the 'general public appears' in that system of representation, it becomes a grandeur projection of the dictatorship and the general masses are always the fantasy or the nightmare of the dictators; therefore these texts always reflect how the dictator is feeling and thinking. These books represent dictatorship discourse, and such is the only reality.

On the contrary, KK Aziz (1993) sees different ground realities and 'vision of history' in Murder of History, his seminal work on the critique of history books used in Pakistan. According to him, it was pre-planned military coup and after that every dictator used the same dominant discourse initiated by him as founding father of dictatorship in Pakistan. Like, 
The Third Knock, his groundbreaking work is highly subversive in nature. He re-examines the history books and argues:

This is a special piece of pleading on behalf of General Ayub Khan, and by implication a defense of all military coups. There was some disorder, democratic norms were not being followed to the full, the Muslim League , under Khan Qayyum Khan, was vociferous and insistent on demanding elections. There was unruly behavior in the assemblies. People in power were not behaving with responsibility. Political waters were ruffled. (All this has been a common feature of Pakistani political culture). But the country certainly did not stand at the brink of a disaster. Neither Iskandar Mirza nor Ayub has any reasonable plea to enter in his defense. Ayub has himself told us in writing that he had been contemplating a military take over since 1954 (152).

It is also interesting to note that the same nexus between dictatorship and capitalism which gave General Ayub khan the power to rule was ended due to the same nexus exposed to the general public. Talbot (2012) pinpoints resistance to Ayub dictatorship under the leadership of Zulfiqar Ali Bhutto, the first elected democratic Prime Minister of Pakistan on economic grounds in the following observation:

Ayub's strategy of challenging resources to tiny entrepreneurial elite in pursuit of his private sector-led development strategy was to bring about his downfall. The Sindhi speaking Zulifaqar Ali Bhutto coordinated the protests of students, workers and lawyers which broke out in West Punjab in November 1968. Ayub eventually stepped down on 25 March 1969 leaving a legacy of enhanced class and regional inequalities in an already fractured state (80).

It is highly pertinent to examine this historical development in The Third Knock which builds its discourse against martial law and the first knock signifies the rise of General Ayub khan dictator ship and the rise capitalist industrial class. In many ways, The Third Knock echoes the analysis of contemporary historians such as Aziz (1993) and Talbot (2012). Here, Mansoor like Bhutto talk to defiance against Haji the symbol of nexus between dictatorship and capitalism:

\section{Mansoor suddenly gets up. His eyes are full of hatred and anger.}

MANSOOR: I ask you how long you will accept being the sacrificial lambs. Isn't it our blood which is in the foundations of this building? You can make several such buildings with the amounts of rent we have paid him over these thirty years. This is our home. How can we vacate our home?

OLD MAN: But...

MANSOOR: You keep on "iffing" and "butting" and they will eat you alive. You keep thinking of an uncertain tomorrow and they are coming to destroy your today. (To Old Man) You say we should plead with him, we should beg for mercy. You are mistaken. He is going to be appeased by begging and pleading, he wants money more and more money. (To Ejaz) You think we can get some relief from the law? Wrong again. An increase in the rent, not going to satisfy his greed. Whatever increase we manage, it will be nothing compared to the profit he will earn from the hotel.

OLD MAN: Then what?

EJAZ: Yes, do you have a solution?

MANSOOR: Yes I have. There is only one solution. A permanent solution. If we go for a temporary solution, the problem will keep coming back. If we compromise, they will keep pushing and pushing. (Pause) Remove the problem from the root, a solution for all time.

ZULFI: What do you mean?

MANSOOR (In a mysterious manner): Yes Haji is haunting our lives like a ghost. Today he is evicting us from this building. Tomorrow he will throw us out from the next building we make our home. Even if we are able to stay for the time being. We will be never be safe here. Violence cannot be eliminated without violence. There is one way of getting rid of this evil. Get rid of him.

OLD MAN: What? You mean us....

MANSOOR (in a dramatic tone): Yes that is what I mean. Get rid of Haji once and for all. He will come here today to get signatures on the documents of our eviction and we will sign his death warrants

EJAZ (Stammering): D-D-Death!

In setting The Third Knock in the historical framework, we have observed that Ajoka theatre created characters representing the political views of the time. Mansoor dialogues reflects the rising zeal in the youth to transform the society and the spirit of the age as Nadeem terms this period as the times "when hope was alive" (Author's note 2008).

Another prominent feature in above mentioned dialogues is the use of emotions. Contrary to the majority of the European and American adaptations of Brecht's plays which misrepresent Verfredmdung (estrangement) by following Martin Esslin "influential but outdated argument that communism rejected all sentiments and emotion and so did Brecht" (Bradely 2011), Ajoka theatre's critical distance towards the action on stage is not designed to replace the 
force of emotions. This 'striking difference' of non-mechanical approach to Brecht adaptation seems one of the major contribution of Ajoka to Brecht's cannon.

Specifically, let's examine the presence of emotional force in Scene 9(a) of The Resistible Rise of Arturo Ui which indicates that Epic theatre does use it. We see a blood stained woman staggers towards the audience and appeals desperately for help and vigilance against fascism, before collapsing under the fire of a machine gun:

THE WOMAN: Help! Help! Don't run away. Who'll testify?

My husband is in that truck! They got him!

Help!

My arm is smashed...And so's the truck. I need

A bandage for my arm. They gun us down

Like rabbits! God! Won't anybody help?

You murderers! My husband! I know who’s

Behind it! Ui ! Raging : Fiend! Monster!Shit!

You'd make an honest piece of shit cry out:

Where can I wash myself? You lousy louse!

And people stand for it! And we go under!

Hey you ! it's Ui!

A brust of machine-gun fire nearby. She collapses

Ui did this Job!

Where is everybody? Help! Who will stop that mob?

Hutcheon (2006) in Theory of Adaptation indicates that the "context of reception is just as important as the context of creation when it comes to adapting"(149). Similarly, Ajoka fully utilized emotions to 'galvanize' the audience of 1970 s by reflecting into Mansoor's emotional force that urge them into standing up against dictators, both now and in the future. "What actually Brecht opposes is emotion as an end in itself: performances that allowed spectators to wallow in the emotions to the characters on the stage, leaving them drained of energy when the curtain fell" (Bradley 2011).

Like Bertolt Brecht, Shahid Nadeem has incorporated strong autobiographical elements into his plays. Here, it can be observed that The Third knock runs parallel to Nadeem own life because some impressions from Nadeem's own life can be seen in it. In the play Nadeem reflected his own experiences against dictatorial regime which he gained before and during his involvement in campaign against Ayub regime which he narrated in the form of Haji. He writes in author's note and thus confirms the new historicism assumption that" literary text is not solely a creation of the author but cultural production like author:" (Greenblatt 1985):

This was the second play I ever wrote. I wrote it in 1970. During 1968-69

I was actively involved in the movement against the military leaders and accused of arson and other violent crimes. General Ayub Khan was finally forced to abdicate in March 1969. However, he was replaced by another military dictator, General Yahya Khan, who proved to be ruthless as his predecessor. I was arrested again and subsequently expelled from the university (1).

Hutcheon (2006) points out adaptations are usually "embedded in the individual histories of the adapters, as well as in the political moments in which they were writing"(106). The statement seems to be highly relevant in case of the transcultural adaptation of Brecht's work in Pakistan. It is pertinent to note that Nadeem like Mansoor, the autobiographical hero of The Third Knock, was also union leader like Nadeem and bitterness he showed against Haji was actually reflective of Nadeem's bitterness against capitalist dictatorship of Ayub Khan. Similarly, Brecht philosophy of standing up against the dictator and showing defiance is reflected in Nadeem which he instilled in his character Mansoor who not only designed the operation against Haji but also convinced others to join in. Mansoor challenges the submissive attitude of others and by providing counter arguments and thus sees the bloody revolution to end Hajis and eliminate this emerged nexus between capitalism and dictatorship to usurp the rights of common masses. In The Third Knock, Nadeem by expressing "poetics of people" (Khan 2005) what is unexpressed in the texts books of history of its time period so therefore subverts the dictatorial dominant discourse.

The historic event unfolds after 10 long years of Ayub dictatorship recorded by some historians in different ways thus showing the 'instability of history discourse' as Greenblatt would say. First, Pro -capitalist writer, Vali Nasr (2009), in his book The Rise of Islamic capitalism, depict the event Mansoor envisioned as:

By 1967, angry and frustrated Pakistanis of all political hues demanded an end to military rule. A robust democracy movement surfaced bringing together secular and religious parties to call for free elections and the return of civilian rule. Those unhappy with growing inequality, which was the result of the rapid economic growth, joined the fray. The opposition took to the streets and as crowd grew larger, Ayub Khan was pressed by his own generals to leave office. In 1969 he 
stepped down, handing power over to the army's chief of staff so he could see to elections and transition to democracy (211).

However, Aziz 's 'history' (1991) does not agree with Nasr attentions about Ayub's attention about elections and transitions to democracy because in that case he should handed over the power to the speaker of the national assembly rather to the army chief. Actually, he pointed out that it was transition from one dictator to another dictator. One knocks to another knock and it was not swift either, "we don't know what happened in the last Ayub -Yaha meeting; the general impression is that the General put a pistol to the head of the Field Marshal and told him where is the exit" (153).

Similarly, Haji first departure was also very dramatic and shows that how dictators cannot withstand when society took 'notice' of them and resist them in public space. Haji restores to threats, pledges, mercy and religion when sees he death coming:

Mansoor holds him by the collar.

HAJI: Leave me! Are you mad? You want to hang upside down in lock- up?

MANSOOR: We have been hanging upside down for years. Now it is your turn.

Zulfi tries to stop Mansoor. Mansoor pushes him away. Ejaz looks on in surprise. Old Man is frightened. Ejaz gets up and Mansoor signals him to come and help. Haji is frightened now.

HAJI: Mansoor, let me go. Listen to me. You can stay on. You can all stay on. I will give you job in my hotel, right here. What do you think? (Mansoor holds him from the neck) I will give money for your sister's treatment. Please let go. I am a heart patient. For God's sake. Have pity. I have small children. Help me someone ... save me in the name of the Prophet Muhammad. I won't charge rent from you. You all live here as long as you...

Mansoor strangles Haji. Ejaz helps and puts his hand on Haji's mouth .Zulfi holds Haji feet. Old Man is stunned. Bi Hajjan shuts the window. Haji body stops writhing. They leave him. The dead body falls to the ground. Silence.

Here Greenblatt's approach to text seems justified. He asserts, in his new historicist work how one text jars against another, producing the possibility, and explores the extents to which discourses of power always shifting, insecure and rife with tensions. In this respect, it can be assumed that Nadeem's view of dictatorship and his characterization of representatives of dictatorship are different from those of the other writers such as Malik(1987), Ziring (1997), Ahmed (1980) and Nasr (2009) who took part in the same episteme in that they appreciated Pakistan military dictatorship and Nadeem was highly skeptical about its benefits and protested both in streets and through his plays. It is therefore evident that The Third Knock subverted the dominant ideology of the time, Capitalist Pakistani military dictatorship.

The Third Knock, in most respects, appears to be a remarkably faithful transcription of the historical situation. Previous studies overlooked to examine the character of Mansoor in light of Bhutto's defiance against Ayub dictatorship. Reexamining the text it appears that Bhutto followed the footsteps of Mansoor and after taking charge as the first elected Prime Minister of Pakistan immediately ousted three star general Gul Hasan and his Air Force colleague in a dramatic fashion on March 4, 1972 and then addressed the nation with resounding confidence to change the status quo. Hussain (1990) observed the confidence when for the first time in Pakistan's history he sees the enforcement of civilian supremacy over the Army. During the speech Bhutto also attacked Bonapartism and also defines it. Here is excerpt:

The people of Pakistan and Armed forces themselves are equally determined to wipe out the Bontapartic influence from the Armed forces. It is essential so that these tendencies never again pollute the political life of Pakistan. Bonapartism is a an expression which means that professional soldiers turn into professional politicians. I use the word Bonapartic because what has happened in Pakistan since 1954 and more openly since 1958 is that some professional Generals turned to politics not as a profession but as a plunder and as a result the influences that crept into Pakistan's social political life destroyed its fabric as the influence of Bonapartism had effect Europe in the 18 th and 19th centuries. But come what may, these Bonapartic influences must be rooted out in the interest of the Armed forces and the people of the Pakistan. (19).

Nadeem also discussed this turbulent time and momentous event thus establishes the relationship of his literary text and its historical position thus his explicit authorial notes contributes to the new historicist theory and justifies my statement about the intrinsic relationship between literary text and the theory that not only theory helps understanding of the literary text but literary text can also contributes to theory:

Those were turbulent times and momentous events were taking place to the region. Pakistan had been dismembered and a civilian government led by Zulifaqar Ali Bhutto took charge in the New Pakistan. Bhutto was overthrown by General Zia-ul-Haq in 1977 and subsequently executed in 1979 and for the next eleven years Pakistan saw its most repressive military rule yet, until Zia was killed in a mysterious plane crash. This vicious circle of dictators replacing popular leaders can be considered as the political context for the murder and re-incarnation of Haji the landlord (1). 
The very presence of Pakistani flag on stage and Baba's babbling and singing patriotic song are highly significant and indicate technique of inversion. His singing of patriotic song subverts the way the national songs are to be taken, because the interaction that encapsulates this song goes in sharp contrast with the spirit of it. He is a "mad old man" but he provides a constant backdrop of partition time against which is put the distorted version of a new world, called Pakistan. So the idea of our land being a great land and our people being great people completely sounds in vacuum. Here the paradox itself becomes a technique of inversion. Through these subversive songs an attempt is made to turn the convention upside down. It can be argued that these conventions in the collaboration with the storytelling tradition , as one see in the adaptation of The Caucasian Chalk Circle, reverse the order of the things and draw attention toward the Brechtian argument that there is need to disturb the status quo.

The striking similarities between Brecht selected play and its two adaptation lies in open ended ending. Unlike previous studies, I argue that the open-ended ness in these literary works suggests the possibility of change. The Third Knock is the play in which the structural repletion takes the form of re-telling. The characters in this play re-live a fantasy that they have owned the building. The surrealistic environment allows three different versions of the story. The first, second and the third knock respectively stand for the three different telling of a story,and in each it is altered to a great degree. In the first scene they kill Haji and start making big future plans. But when there is a second knock they all become alert and suspicious of their act, whether they have killed Haji or not. The result is reshaping of what they have already said in the first secene . where the residents have individually pleaded Haji in previous scene, now Ejaz alone rephrases what they said separately:

EJAZ (pointing toward Baba): His whole family was cut down in the partition riots. He is all alone now. (Pointing towards Old Man) And he was robbed of everything. He came to this country with just the clothes he was wearing....(Jamila coughs).And her youth has been eaten up by the worms of hunger and (towards Mansoor) he is an outstanding plumber, but there is no job for him. These people never even dared to dream of light and the fresh air (41).

The emotional impact of this kind of telling is different from that of the story told by the original narrators. In the scene titled "The Second Knock", which is a re-working of the earlier scene, the story's ending is changed. The strangle Haji again in the scene but with the consequence that they are all arrested, except the women, old Man, and Baba, the mad man. The open -endedness of the third scene presents completely another version of the story. These "three versions of the same story are a dramatic representation of the way in which a story changes in the re-telling and how difficult is to claim that a retold story is the same as the original" (Bowles 125). The interactive mode and the local context allow modifying the stories each time is re-told. The repetitive structure in itself becomes a tool of revision, which hints at the possibility of change.

\section{Bala King: Birth of a Pakistani Arturo Ui}

Bala king was first performed in March 1998 to mark the 100th Birthday of Brecht. Khatoon (2011) expresses the impact of indigenization of Brecht's play as:

When performed on the stage the audience refused to believe that Bala King was an adaptation of a play written by European dramatist. The story seems familiar as the play perfectly dramatizes the glorious autocratic rule that our pragmatic politicians exercise. Everyone believed that it was Pakistan's story. One would have thought that its adaptation into local language would have resulted in the essence being lost in translation. On the contrary, its appreciation reveals that similar political problem plague countries irrespective of difference of language or culture (26).

However, Welch (1993) disagrees with the universality of the Nazism and declares it "largely the product of the peculiarities unique to German history and political culture" (1). Similarly we see that in adapting Brecht's selected text, Ajoka centers on its historical events rather than translating Brecht's narration thus giving it more indigenized look that was the prime reason the adaptation met the audience's expectation of horizon. Especially in second adaptation Ajoka took the many liberties and based Pakistan's checkered history as the context of the play, The Third Knock as another vision of history rarely discussed before in theatrical space.

Like in Tekey Da Tamasha (adaptation of The Threepenny Opera) we also observe the politics of location plays the cardinal role in engagement for the audience. Again Ajoka focused on Tibi district, a business hub, which is constituency of Main Muhammad Nawaz Sharif thus re-contextualizing the setting into interior Lahore Ajoka gave audience the message to see the relationship of location and the rise of a civilian dictator they wanted to present. In Capitalism's In Capitalism's Achilles Heel, Baker (2005) explains the reasons behind the gradual rise of Nawaz Sharif and nexus between capitalism and dictatorship which was the central theme in Bala King. He reveals:

While Benazir Bhutto hated the generals for executing her father, Nawaz Sharif early on figured out that they held the real power in Pakistan. His father had established a foundry in 1939 and together with six brothers had struggled for years only to see their business nationalized by Ali Bhutto's regime in 1972. This sealed decades of enmity between the Bhuttos and Sharifs. Following the military coup and General Zia assumption of power, the business-Ittefaq-was returned to family hands in 1980. Nawaz became a director and cultivated relations with senior military officers. This led to his appointment as finance minister of Punjab and then election as chief minister of this most populous province in 1985 (82).

Baker then explores in the link between political and economics in Pakistani context and asserts that they have intrinsic relationship in promoting his rise to power: 
During the 1980s and early 1990s, given Sharif's political control of Punjab and eventual prime minister ship of the country, ittefaq Industries grew from its original single foundry into 30 businesses producing steel, sugar, paper, and textiles, with combined revenues of $\$ 400$ million, making it one of the biggest private conglomerates in the nation. As in many other countries, when you control the political realm, you can get anything you want in the economic realm (82).

Consequently, Nawaz Sharif became so powerful by controlling political and economic realm that he started like Hitler to acquire virtually dictatorial powers and here Ajoka resisted with series of Brecht plays adaptations, firstly, in The Threepenny Opera in form of Fooka Terrror and then in The Resistible Rise of Arturo Ui in the role of Bala King. Booker provides the details of this stage in Nawaz Sharif's resistible rise to full blown dictatorship by combining business, politics, and religion together:

What brought down in his second term was his attempt to acquire virtually dictatorial powers. In 1997 he rammed a bill through his complaint parliament requiring legislators to vote as their part leaders directed. In 1998 he introduced a bill impose Sharia Law (Muslim religious Law) across Pakistan, with himself empowered to issue unilateral directives in the name of Islam. In 1999 he sought to sideline the army by replacing Chief of Staff Pervez Musharraf with a more pliable crony. He forgot the lessons he learned in the 1980s: The army controls Pakistan and considers politicians as a nuisance (84).

Another debatable issue is the function of 'spectacle' in the adaptation of The Resistible Rise of Arturo Ui to "package it into attractive theatre" ( Nadeem 1998). The beating of Dohl (drums) and colorful costumes with elaborate setting which evoked an atmosphere of interior Lahore which was at once familiar and local in color but also decreased the revolutionary potential of Ajoka as an agent for change. It also seemed to contradict Brecht's views on spectacle who wanted it to be 'simple' as much as possible.

Specifically, Austrian playwright Peter Handke remarks are also significant in the role of spectacle in political theatre who states that politics is assumed to be sphere of action, definitive and committed ; the opposite of theatre which , as a make-believe game, automatically transposes it subjects and actors into symbols. For theatre to be politically effective every element of pretence must be eliminated" (47). Khan (2005) pinpoints at spectacle by comparing both Ajoka and Lok Rehas "Street Theatre in Pakistani Punjab":

Ajoka's political and message often gets lost in spectacle: colorful costumes, hypnotic dances, increasingly elaborated sets. Conversely, Lok Rehas gets critique by both sophisticated urban and rural audiences, as well as its rival counterparts, for lacking enough action and spectacle (196).

To further indigenize the selected text $\mathrm{Ui}$ is replaced by Bala King, an unemployed pehlwan (Wrestler) gang leader, who decides to leave the Texali gate adda and try his fortunes in the Badami Bagh world of intercity road transport. Badami Bagh is ruled by self-righteous businessmen, ready to trade all principles for business gains and lucrative contracts. Bala and his gang exploit the vulnerability and contradictions of these groups, aided by their muscle power. He bribes, blackmails and intimidates the businessmen and the shopkeepers to accept his protection at very heavy premium. Bala Pehlwan changes his name to Bala King, receives lessons in public speaking and political science and eliminates all opposition, circumvents law and public opinion and eventually establishes his absolute control over the area. The rise of Bala King and the inability of the people in resisting the dictatorial advances expose the inherent weakness of our society and its vulnerability to violence, blackmail, and corruption.

This adaptation also reflects that Brecht social and political philosophy is as relevant in Pakistan as it was in Germany and Europe in the 40s. Bala King, though an adaptation, is a very relevant and meaningful play for the Pakistani audience, where spectre of autocratic rule looms large, where violence and crime appear to pay politically and where a complacent and acquiescent majority seems helpless against the forces of corruption, crime and violence. Nadeem himself detached his plays from other cultural artifacts whose function is to reflect reality. In his preface to Selected Plays (2008), "Changing World" published by Oxford University Press, Nadeem had declared a manifesto (very Brechtian in spirit) concerning the function of his plays performed by Ajoka Theater across the world:

I have written in primarily for a Pakistani audience and Pakistanis yearn for change. There is so much to which needs to be changed. Not just the unjust capitalist system but also the social contradictions, the double standards, the discrimination, dictatorship tendencies over our rulers and hatred and violence. I have always found my themes from what I see around me. I observe, retaliate, reject and I use my power to edit and remodel reality my way (xxviii).

These above mentioned elements in his writing seem reflection of social action theatre envisioned by Brecht called 'Epic' in response to the political and social upheaval caused by the historical events in early twentieth century. What makes the plot relevant to Pakistan is the use of typical urban local satirical songs, and the culturally rich lorry "adda" environment. Specifically, the use of local language is utilized not only to cater to the taste of local audience and to reach the common masses but is also used as a tool of resistance to linguistic imperialism. Khan has drawn attention to this linguistic dimension of the performance, "In using Urdu and Punjabi to replace / construct a Europian idiom and language, Madeeha and Shahid have very consciously formulated a practical resistance to linguistic imperialism rooted I pre-independence British colonial past" (63). Gohar has also called attention to this facet of her work in an interview published in 1991. She says "..... Stress should be laid on the performing Urdu and Punjabi plays because every act of creation has its roots in its own reality. Moreover, it does not imply artificial situation and you can more easily reach toward greater number of audience". However we see a drastic change in the linguistic strategy when Ajoka entered 
into the international sphere and trans-created its almost all plays in English and which declared by Khan (2009) as a pragmatic policy of Ajoka keeping the view of the importance of English language (12).

Another thought provoking issue is the historical positioning and 'significance re-creation' of the play through repeated performances, which is overlooked by the previous studies. It shed light how political theatre has the potential to generate counter discourse and trigger meaningful events in history (Greenblatt 1985). Let's re-visit the performance history of the play which indicates three years 1998, 2005, 2009. In 1998 Ajoka premiered the adaptation when Sharia Bill was launched, a connection between Zia-ul-Haq and Nawaz Sharif was already established, and the liberal forces took notice of this adaptation and widely quoted it in the newspaper reviews and asked the question what Brecht asked in 1941 that who will stop him? At that point of time even the establishment realized that "Bala "was out of hand" and finally they showed him the way to exit as did they did with military dictator Ayub khan. Nawaz Sharif was exiled to Saudi Arabia in 2000 "with twenty two containers of carpets and furniture followed and of course his foreign accounts remained mostly intact” (Booker 2004).

Second, performance in 2005 was to celebrate its departure from the political scene of Pakistan and to endorsed Musharraf regime for getting rid of him which also highlights the personal enmity between Nadeem and Nawaz Sharif triggered when later expelled him from the post of general manager of the state Television Channel in 1996. Khan (1997) pointed out the "policy of opportunism" in Ajoka's work. She writes:

In 1994, a development that further complicated Ajoka's commitment to political theatre was that its playwright and Madeeha's husband, Shahid Nadeem, was appointed Lahore Television's general manager. As a result, by 1996, several of Ajoka plays were performed on television. What remains to be seen is whether Ajoka can maintain its politically subversive edge and independence or whether its politics will become seriously compromised as a result of this foray into government sponsored territory.

Interestingly in 1997, when Nawaz Sharif came to power after the dismissal of Benazir Bhutto's government on charges of corruption, Shahid Nadeem was fired immediately.

It should be noted that it is the same year (1997) Ajoka performed Bala King and exposing Nawaz Sharif's resistible rise to power it can be argued that one of main reason to adapt The Resistible Rise of Arturo Ui was to theatrically respond to the allegation leveled by Nawaz Sharif and to tarnish the 'political image' of him in public sphere.

Thirdly, the repeated performances of Bala King highlight the rekindling of fear in Ajoka camp when Saudi Arabia negotiated its exile with the establishment and he successfully landed in Pakistan in 2007 and started to actively participate in politics in 2010. The brochures of Bala King and advertisements again asked "Who will stop Bala King Now? Is there any!” ( Musafat theatrical Festival 2009).

\section{Conclusion}

'Politics' of staging capitalist dictatorship resolves around the conflict between dictatorial forces to control power structures and pro-democratic forces to resist them during their historical milieu. Brecht highlighted the nexus between the bourgeoisie class and capitalism which gives birth to the need of fascist and capitalist dictatorship to sustain and keep it healthy. Brecht selected work and Ajoka's two transcultural adaptations; The Third Knock and Bala King exhibit the power dynamics of this relationship and its consequences and ask society to 'act 'as an interventionist variable in their particular historical frame work. It is argued that transcultural adaptations of Brecht's selected work as overt challenges to the political conformities of their days and therefore we can place their work as an advance guard of the democratic revolution in Pakistan. Finally, re-examining the new historicist dimensions of The Resistible Rise of Arturo $U i$ and its transcultural adaptations pinpoints another 'vision of history' silenced by the dictators and their protégés. The study located the selected texts in the complex web of power relations and cultural representations which exhibited that the selected texts are, in fact, force de tour and subversive to dominant dictatorship discourse enormously supported in textbooks written during their times.

\section{References}

Abdi, R. (1987). Tragic Vision: The Western Drama and Modern literary Movements. Lahore: Punjab University Press. Ajoka, P. (2009). Bala King. By Bertolt Brecht. Adpt. Shahid Nadeem. Dir. Madeeha Gohar, Alhamra Theatre, Lahore. 8. Performance

Ayaz, B. (2012). What's wrong with Pakistan? Delhi: Hay House Judia. Print.

Aziz, K.K (1993). The Murder of History .Lahore: Vangaurd Press.

Baker, W. R.(2005). Capitalism's Achilles Heel, New Jersey: John Wiley \& Son.

Brecht, B.(1997). Collected Plays: Three. London: Methuen. Print.

Ezrow and Frantz (2011) in their comprehensive work on dictators and dictatorship: Understanding Authoritarian regimes and their leaders.

Fischlin, D. and Fortier M. (2000). Adaptations of Shakespeare. London: Routledge. Print.

Foucault, M. (1995). Discipline and Punish: The Birth of a Prison. Translated by A. Sheridan. New York: Vintage. Print. 
Greenblatt, S. (1985). Introduction: The forms of Power and the powers of Forms in the Renaissance”, Genre 15.

Hutcheon, L. (2016). A Theory of Adaptation. New York: Routledge. Print.

Khan, Fawzia A. (2005). A Critical Stage. Calcutta: Seagull Books. Print.

Khatoon, S. (2011). "Brecht in Pakistan". Exploration 22,18-30. Print.

Nadeem Sh. (2008). Selected Play, New York: Oxford University Press. Print.

-- (2008).Preface. Selected Plays by Shahid Nadeem. New York: Oxford University Press.

-(2005). Rev. of Kashmir Times. The Third Knock by Shahid Nadeem. Jammu, Print. 279-280.

Nasr, V. (2009). The Rise of Islamic Capitalism. Colorado: Kumarian Press.

Rahman, T. (2012). The class structure of Pakistan. Karachi: Oxford University Press. Print.

Sporre,J. D. (1993). The Art of Theatre, New Jersey: Princeton Hall. Print.

Squiers, A. (2012). The Social and Political Philosophy of Bertolt Brecht, PhD dissertation, Western Michigan University.

Sulieman, A. (2011). Studies in Modern Drama: Bertolt Brecht, Mosul: Mena Publisher.

Talbot, I. (1993). Pakistan: A New History. Karachi: Oxford University Press. Print

Welch, D. (2012). The Third Reich: Politics and Propaganda. London: Routledge.

Williams, M. (2014). New Historicism and Literary Studies. New York : Routledge.

Ziring, L. (1997). Pakistan in the Twentieth Century: A Political History. Karachi: Oxford University Press.

------- (1967). The Ayub Khan Era: Politics in Pakistan, 1958-1969, New Jersey, Syracuse University Press. 